Winter 2006

\title{
Protecting Families in a Global Economy
}

Kenneth G. Dau-Schmidt

Indiana University Maurer School of Law, kdauschm@indiana.edu

Carmen Brun

Sutherland Asbill \& Brennan

Follow this and additional works at: https://www.repository.law.indiana.edu/ijgls

Part of the Family Law Commons, International Law Commons, and the Law and Economics

\section{Commons}

\section{Recommended Citation}

Dau-Schmidt, Kenneth G. and Brun, Carmen (2006) "Protecting Families in a Global Economy," Indiana Journal of Global Legal Studies: Vol. 13 : Iss. 1 , Article 6.

Available at: https://www.repository.law.indiana.edu/ijgls/vol13/iss1/6

This Symposium is brought to you for free and open access by the Law School Journals at Digital Repository @ Maurer Law. It has been accepted for inclusion in Indiana Journal of Global Legal Studies by an authorized editor of Digital Repository @ Maurer Law. For more information, please contact rvaughan@indiana.edu.

\section{$\Psi$}

JEROME HALL LAW LIBRARY

INDIANA UNIVERSITY

Maurer School of Law
Bloomington 


\title{
Protecting Families in a Global Economy
}

\author{
Kenneth G. Dau-Schmidt* and Carmen Brun**
}

\begin{abstract}
The globalization of the economy has placed tremendous pressure on the modern family. Throughout the developed world, marriage rates are declining, birth and fertility rates are falling, real wages are flat or declining, and hours of family external labor supplied are rising. Finding a spouse and raising children can be inconsistent with the demands of careers in the global economy of the new information age. Globalization of the economy tends to encourage individualism and mobility, in direct opposition to family relationships. Moreover; the extensive period of training that is necessary to compete in the global economy interferes with marriage and childrearing and increases the costs of raising children. Finally, the global economy has resulted in increased demand for flexible labor, requiring many lower-and middle-class families to increase time spent in the paid workforce, often with few or no additional benefits.

This essay examines the different ways industrialized countries have responded to these problems and discusses the effectiveness of these possible solutions in the context of the global economy. In Part I, we present a definition of the family and some of the costs and benefits of family relationships. In Part II, we explore the reasons behind the current underinvestment in families, including the demands of the marketplace and government policies that promote market labor and undervalue children. In Part III, we discuss the "new" family and the fact that people are getting married less, and later in life, having fewer children, and spending less time raising children. Finally, in Part $I V$, we survey the ways in which several industrialized countries have addressed the problems of families in the global economy both through the market and government policies.
\end{abstract}

*Associate Dean of Faculty Research; Willard and Margaret Carr Professor of Labor and Employment Law, Indiana University-Bloomington; Ph.D. (Economics) 1984, J.D. 1981, M.A. 1981, University of Michigan; B.A. 1978, University of Wisconsin.

**Associate, Sutherland Asbill \& Brennan, Washington, D.C.; Snyder Visiting Scholar (fall 2005), Lauterpacht Centre for International Law, Cambridge, England; J.D. 2005, Indiana University School of Law-Bloomington; M.B.A. 1990, Kelley School of Business, Indiana University-Bloomington; B.A. 1988, Indiana University-Bloomington. 


\section{INTRODUCTION}

What greater thing is there for human souls than to feel that they are joined for life-to strengthen each other in all labor, to rest on each other in all sorrow, to minister to each other in all pain, to be with each other in silent unspeakable memories?

-George Eliot, Adam Bede

The family is both the fundamental unit of society as well as the root of culture. It represents a child's initial source of unconditional love and acceptance and provides life-long connectedness with others. The family is the first setting in which socialization takes place and where children learn to live with mutual respect for one another.

\section{-Marianne E. Neifert, Dr: Mom's Parenting Guide}

The family is under tremendous pressure in the modern world. In the United States, Europe, and Japan, marriage rates are declining, birth and fertility rates are falling, real wages are flat or declining, and hours worked outside the home are rising. ${ }^{1}$ To the extent that people desire these changes and the modern world merely affords them the opportunity to live as they want, these changes are all for the better. However, there is increasing evidence that the demands of the modern world are impinging on people's desire to find a spouse and raise children. ${ }^{2}$ These trends are also straining the labor resources of families, directly impacting the ability of people to care for children, and even indirectly impacting the financing of a country's social security and health plans and immigration policy. ${ }^{3}$

1. See generally Gary Martin \& Vladimir Kats, Families and Work in Transition in 12 Countries, 1980-2001, Monthly La B. Rev., Sept. 2003, at 3, available at http://www.bls.gov/opub/mlr/2003/ 09/artlfull.pdf (discussing changes to the family structure over the last 20 years of the 20th century).

2. See infia Part III-The Modern Family in the Global Economy.

3. The effects of the modern world on families have not all been negative. Some families have experienced higher incomes, greater job opportunities, better health, and better educational opportunities. Unfortunately, many of these benefits have not been evenly distributed. Don S. Browning, Marriage and Modernization: How Globalization Threatens Marriage and What to Do About It 4 (2003). 
Globalization is one of the key factors in the disruption of the family. ${ }^{4} \mathrm{Al}-$ though the economy of traditional agrarian societies depended on marriage and childbearing to supply the necessary labor for production, ${ }^{5}$ finding a spouse and raising children can be inconsistent with the demands of careers in the global economy of the new information age. Globalization of the economy tends to encourage individualism and mobility, in direct opposition to the collectivity and stability necessary for successful family relationships. ${ }^{6}$ Moreover, the extensive period of training that is necessary to compete in the global economy at a livable wage not only interferes with the establishment of marital relations and childrearing, but also increases the period of child dependency, thus increasing the costs of raising children. ${ }^{7}$ Finally, the global economy has resulted in an increased demand for flexible labor, requiring many lower-and middle-class families to increase time spent in the paid workforce, often with few or no additional benefits. $^{8}$

This essay will examine the different ways industrialized countries have responded to these problems faced by modern families and discuss the effectiveness of these possible solutions in the context of the global labor economy. In Part I, we present a definition of the family and some of the costs and benefits of family relationships. The concept of family has greatly evolved over the last few decades. For some, only marriage or a blood relationship forms a family. For others, these are no longer requirements. In Part II, we explore the reasons behind the current underinvestment in families: people underinvest in relationships and children due to the pressing day-to-day needs of survival; government policies promote paid labor over home labor; workplace training and careerbuilding occurs during the prime relationship-forming and childbearing years; and the government fails to treat children as a public good. In Part III, we discuss the "new" family and the fact that people are getting married less, and later

4. See id. at 1 .

5. See Noriko O. Tsuya \& Larry L. Bumpass, Introduction to Marriage, Work, and Family Life in Comparative Perspective 1, 1 (Noriko O. Tsuya \& Larry L. Bumpass eds., 2004).

6. See Don Edgar, Globalization and Western Bias in Family Sociology, in The Blackwell Companion to the Sociology of Families 3, 3-4, 8 (Jacqueline Scott et al. eds., 2004).

7. See id. at 8; Sylvia Ann Hewlett, Executive Women and the Myth of Having It All, Harv. Bus. Rev., Apr. 2002, at 66, 69. See also infra Part II.D. Cf. Linda J. Waite \& Mark Nielsen, The Rise of the Dual-Earner Family, 1963-1997, in Working Families: The Transformation of the AmeriCAN Home 23, 24 (Rosanna Hertz \& Nancy L. Marshall eds., 2001).

8. See Martha T. McCluskey, Subsidized Lives and the Ideology of Efficiency, 8 AM. U. J. Gender Soc. PoL'Y \& L. 115, 117 (2000). 
in life, and, as a result of both of these factors, having fewer children. Modern families are also spending more time in the paid labor market and less time raising children. Finally, in Part IV we survey the ways in which several industrialized countries have addressed the current underinvestment in families and explore how both markets and governments of industrialized countries have responded to the needs of families in the global economy.

\section{THE FAMILY}

\section{A. A Definition of the Family}

For the purposes of this essay, we will define the family as a collection of people, bound together in a committed relationship, for the purpose of maximizing their joint benefit in their interaction with each other and the outside world. What constitutes the joint benefit of the family is determined by the family members through joint decisionmaking or "bargaining" within the context of social norms. Although the traditional conception of family is based on a legal marriage between a man and a woman and the resulting children, such a narrow conception of the family is not necessary for our argument. The basis of the family members' commitment might be marriage, blood relationship, legal custody, or "merely" love. There may be one parent, or two; the founding partners may be of the same gender, or different genders. Our concern is not with how people organize themselves into families, but only that they be able to realize this basic expression of human nature without undue interference from the demands of their jobs and the global economy. ${ }^{9}$ Our conception of the family is consistent with the definition adopted by the United Nations in some of its statistical analyses, which define family "as a group of two or more persons within a private or institutional household who are related as husband and wife, as cohabitating partners, or as a parent and child." 10

9. Later, we will present evidence on the breakdown of the traditional family, but we do so because we see this as a proxy for the strains all families are under, not because we think there is one necessary form for the family.

10. United Nations, Economic and Social Council, Statistical Commission and Economic Commission for Europe, Conference of European Statisticians, Statistics of Households and Families in Member Countries of the CES, I 9, U.N. Doc CES/2003/19 (June 3, 2003) (prepared by Nico Keilman and submitted by Statistics Norway), available at http:/www.unece.org/ stats/documents/ces/2003/19.e.pdf. Some countries, like Norway, even go as far as defining a family as a one-person household. Id. 


\section{B. The Benefits and Costs of Family}

Although dependent on the quality of the relationship, ${ }^{11}$ there are many benefits from binding together into a family, regardless of how it is defined. Sharing a committed, loving relationship with another person is both emotionally and financially rewarding. Marriage has been shown to improve an individual's happiness and emotional well being. ${ }^{12}$ Married couples are more sexually satisfied than their unmarried counterparts. ${ }^{13}$ Studies have shown that married people have improved physical and mental health and experience lower risks of mortality. ${ }^{14}$ Married couples tend to communicate more with each other ${ }^{15}$ and become more connected to the greater community. ${ }^{16}$ Marriage also helps couples accumulate wealth because not only can couples pool their resources, but also because men are generally more productive in marriage, earning 10 to 40 percent more than their single counterparts. ${ }^{17}$

Furthermore, a committed, loving relationship facilitates childrearing. The burdens of providing income and childcare are lighter if two responsible adults share them. Children also benefit, both economically and emotionally, from stable, high-quality family relationships. Children in married households are more likely to graduate from college, find good jobs, and start their own families. ${ }^{18}$

11. See Sinikka Elliott \& Debra Umberson, Recent Demographic Trends in the US and Implications for Well-Being, in The Blackwell Companion to the Sociology of Families, supra note 6, at 34,37 .

12. See Noriko O. Tsuya et al., Views of Marriage Among Never-Married Young Adults, in Marriace, Work, and Family Liffe in Comparative Perspective, supra note 5, at 39, 44.

13. David Popenoe \& Barbara Dafoe Whitehead, Ten Important Research Findings on Marriage and Choosing a Marriage Partner, Info. Brief (Nat'l Marriage Project), Nov. 2004, at 2, available at http://marriage.rutgers.edu/Publications/pubTenThingsYoungAdults.pdf.

14. See Elliott \& Umberson, supra note 11, at 36; United Nations Development Programme, Human Development Report 1999, at 77 (1999) [hereinafter UNDP Report], available at http:// hdr.undp.org/reports/global/1999/en/pdf/hdr_1999_ch3.pdf.

15. See Popenoe \& Whitehead, supra note 13, at 2.

16. Healthy Marriage: What Is It and Why Should We Promote It?: Hearing Before the Subcomm. on Children and Families of the S. Comm. on Health, Education, Labor; and Pensions, 108th Cong. 18 (2004) (testimony of Barbara Dafoe Whitehead, Co-Director, National Marriage Project, Rutgers University) [hereinafter Whitehead Testimony], available at http//marriage.rutgers.edu/Publications/ Pub\%20Whitehead\%20Testimony\%20Apr\%2004.htm.

17. Popenoe \& Whitehead, supra note 13, at 2; Whitehead Testimony, supra note 16 , at 19.

18. See Browning, supra note 3, at 18; Whitehead Testimony, supra note 16, at 22. 
Male children who have grown up in households with married parents are more likely to have positive attitudes toward women and a family life of their own. ${ }^{19}$

Of course, there are also costs to family relationships. Committing to a partner requires time and energy and constrains the choices one can make in one's career. Working women may perceive their careers "as a dissociation from family obligations. ${ }^{20}$ Children require an even greater commitment of time, energy, and sacrifice of career. In a recent study among European youth, many prefer to enjoy the single life and get an education; they have not yet thought seriously about marriage or having children. ${ }^{21}$ Some of these youths believe that having a child would "hinder their ambitions for either a 'good social life' or for employment."22 These feelings are well founded because the forgone wages from raising a single child may well exceed one million dollars, even for people of moderate income. ${ }^{23} \mathrm{Chil}-$ dren also involve a significant investment in food, clothing, entertainment, and education. For example, in Japan there is tremendous pressure on parents to send their children to the best schools, but this can be quite expensive. The increasing educational costs associated with raising a child in Japan have become a wellrecognized deterrent to childbearing. ${ }^{24}$ In the United States, it has been estimated that the out-of-pocket costs associated with supporting a middle-class child until eighteen years of age is more than $\$ 200,000 .{ }^{25}$ For many, the problems of balancing family and career, and the increasing costs of childrearing, are limiting the number of children they want to bear. ${ }^{26}$

19. Whitehead Testimony, supra note 16, at 23.

20. See Margret Fine-Davis et al., Fathers and Mothers: Dilemmas of the Work-Life BalANCE 37 (Social Indicators Research Series No. 21, 2004). A career also allows a woman to feel more like an adult. Previously, women did not feel like an adult until they were either married or had children. Id.

21. See Julia Brannen \& Ann Nilsen, Young People's Perppectives on the Future, in Young Europeans, Work and Family: Futures in Transition 48, $53-54$ (Julia Brannen et al. eds., 2002); Julia Brannen et al., Imagining Parenthood and Employment: Connected or Disconnected Worlds?, in Young Europeans, Work and Family: Futures in Transition, supra, at 116, 121.

22. Brannen et al., supra note 21 , at 121.

23. Phillip Longman, The Global Baby Bust, Foreign Aff., May-June 2004, at 64, 65.

24. See Noriko O. Tsuya \& Minja Kim Choe, Investments in Children's Education, Desired Fertility, and Women's Employment, in Marriage, Work, and Family Life in Comparative PerspecTIVE, supra note 5 , at 76, 76-77.

25. See Longman, supra note 23 , at 66 . This figure does not include the cost of college or the lost wages to parents, which can amount to over $\$ 1$ million. Id.

26. See Fine-Davis Et al., supra note 20, at 37; See Tsuya \& Kim Choe, supra note 24, at 76. 


\section{The Problem of Underinvestment in Families}

People have to make a considerable investment of time, energy, and resources in order to successfully organize families and raise children. We would argue that, because of the demands of the global economy, there is currently an underinvestment in families and children by individuals, the market, and governments. There are several reasons for this underinvestment: the pressing dayto-day needs of survival, government policies promoting market participation over home participation, workplace training and career-building that occurs during prime relationship-forming and childbearing years, workplace practices that needlessly disadvantage people in relationships or parents with children, and the failure of governments to treat children as a public good.

\section{A. The Pressing Day-to-Day Needs of Survival}

The first issue frustrating investment in the family is the pressing day-to-day needs of survival. Families are sometimes forced to adopt strategies of underinvestment that are destructive in the long run, in order to survive today. As discussed above, the costs of childrearing can be great. Although wealthy families may be able to adjust to economic downturns, or unplanned pregnancies, and still maintain an adequate level of investment in their children, poorer families that eke out a marginal existence may have no choice but to cut the costs of childrearing, even to the detriment of their children. To adjust the number of members in the family, and jettison some when times are tough, undermines the importance of mutual love and support in the family. Borrowing against possible future earnings is also not a realistic option for families living a marginal existence because lenders either will not make loans secured only by illiquid assets or will do so only at a penalty rate of interest. Examples of underinvestment in the future to survive today are rampant in the developing world where parents must pack their children off to factories and mines, rather than to schools, in order to make enough to survive. ${ }^{27}$ Although providing a less dramatic example, poor families in the developed world also are sometimes forced to underinvest in their children, in order to make ends meet. ${ }^{28}$

27. See Jude L. Fernando, Children's Rights: Beyond the Impasse, Annals Am. Acad. Pol. Soc. Scr., May 2001, at 8, 14; Brian D. Gallagher, A Brief Legal History of Institutionalized Child Abuse, 17 B.C. Third WorLd L.J. 1, 24 (1997).

28. See Marleen O'Connor-Felman, American Corporate Governance and Children: Investing in our Future Human Capital During Turbulent Times, 77 S. CAL. L. REv. 1255, 1306-07 (2004). 


\section{B. Government Policies Promoting Market Participation Over Home Participation}

Underinvestment in the family can also be the result of government policies. Some governments have implemented policies that encourage, and almost compel, families to participate in the market and underparticipate at home. For example, in the United States, coverage in the nation's social security program is predicated on participation in the paid labor force for a minimum number of calendar quarters. Homemakers who do not participate in the paid labor market are not insured in case of their death or disability, and they do not earn an old-age pension based on their own work..$^{29}$ Similarly, in the United States, the primary method of providing medical insurance is through paid employment. Billions of government dollars are "spent" each year in the form of tax breaks to complying health and pension plans in order to encourage private employers to provide these benefits. ${ }^{30}$ Although there are government medical insurance programs for eligible poor and aged in the United States, absent eligibility for one of these programs, the clear incentive of government policy is for labor outside of the home.

The policies of the Fair Labor Standards Act (FLSA) ${ }^{31}$ also encourage increased paid labor force participation among some workers. Although the FLSA requires employers to pay most employees an overtime wage for hours worked in excess of forty per week, ${ }^{32}$ executive and professional employees are exempt from this requirement. ${ }^{33}$ Rather than hiring additional labor, the employers of executive and professional employees have incentive to work these employees more than forty hours per week in order to save on employee benefits. ${ }^{34}$

Perhaps the clearest example of government policy promoting paid labor over home labor is the Temporary Assistance to Needy Families program in the

29. See 42 U.S.C. $\S \S 402,414$ (a) (2005). See also Social Security Admin., Social Security ReTIREMENT BeNEFITs 3 (2004), available at http://www.ssa.gov/pubs/10035.pdf.

30. In fiscal year 2001 , the government revenue lost due to tax advantages to encourage private employer pensions was $\$ 93$ billion, and the revenue lost due to tax advantages to encourage private employer health insurance was $\$ 84$ billion. Executive Office of the President of the U.S., Office of Mgmt and Budget, Analy tical Perspectives: Budget of the United States GovernMENT: Fiscal Year 2002, at 64-65 tbl.5-1 (2001).

31. 29 U.S.C. $\$ \$ 201-219$ (2005); see also Vicki Schultz \& Allison Hoffman, The Need for a Reduced Workweek in the United States 7 (Yale Law School, Public Law \& Legal Theory Research Paper Series No. 91, 2004), available at http//papers.ssrn.com/sol3/papers.cfm?abstract_id $=618801$.

32. 29 U.S.C. $\$ 207(2005)$.

33. 29 U.S.C. $\$ 213(2005)$.

34. Schultz \& Hoffman, supra note 31 , at 7. 
United States. ${ }^{35}$ Although this program focuses on the family and decreasing the amount of dependence upon social programs, it does so by requiring parents to work and/or participate in job training; otherwise, these parents risk losing part or all of their federal assistance. ${ }^{36}$

\section{The Demands of the Global Economy for Greater Flexibility in Employment}

The globalization of the economy, combined with developments in information technology, have undermined long-term employment relationships and expanded relevant labor markets to areas of national, or even international, relevance. ${ }^{37}$ International free trade agreements and improvements in communication and transportation have placed workers around the world in competition with each other. Moreover, developments in information technology have allowed new market-driven managerial techniques, the vertical disintegration of firms, and the outsourcing of work around the world. ${ }^{38}$ As a result, long-term stable employment is giving way to contingent employment, and workers are compelled to undertake more job and geographic dislocations in order to pursue their careers. ${ }^{39}$

The formation and propagation of families suffers in such an environment. While the global economy demands workers with individual freedom for mobility, families need collectivity and stability to take root and grow. ${ }^{40}$ Couples need time together in order to develop the love and commitment on which families are founded. ${ }^{41}$ To successfully raise children requires even more stability. Children do better in school, acquire more friends, and develop a healthier attitude toward life if they enjoy a healthy, stable home environment in which to

35. 42 U.S.C. $\$ 601$ (2005) (providing assistance to needy families so that children may be cared for either at home or in the home of relatives while the parents are either working or receiving job training).

36. 42 U.S.C. $\$ 607(d)$, (e) (2005); see also Lynn D. Wardle, The "Withering Away" of Marriage: Some Lessons from the Bolshevik Family Law Reforms in Russia, 1917-1926,2 Geo. J.L. \& Pub. PoL'y 469,515 (2004).

37. Kenneth G. Dau-Schmidt, Employment in the New Age of Trade and Technology: Implications for Labor and Employment Law, 76 Ind. L.J. 1, 2 (2001); Peter Cappelli, The New Deal at Work: Managinc the Market Driven Workforce 1 (1999).

38. Dau-Schmidt, supra note 37 , at $10-12$.

39. Id. at 13.

40. See Edgar, supra note 6, at 3-4.

41. Cf. Elizabeth S. Scott, Marriage, Cohabitation and Collective Responsibility for Dependence, 2004 U. Chi. Legal F. 225, 245-46; Strategies for Blending Your Family, Ebony, July 2005, at 131. 
grow. ${ }^{42}$ Geographic dislocations can also separate families from the support systems they might otherwise have in grandparents or other relatives. The problem of employment instability has been compounded by the fact that now both men and women work outside the home, and most people find two careers necessary for the expenses of raising children. Twice the number of careers per family increases the chances of job and geographic dislocation.

\section{The Conflict Between Training and Family Growth in the Prime Relationship- Formation and Childbearing Years}

Both the globalization of the economy and new information technology have also raised the amount of training workers must undertake in order to remain employed. ${ }^{43}$ The outsourcing of low-skilled jobs to developing countries ensures that workers in developed countries must attain ever-greater levels of training in order to stay employed, while the development of new information technology ensures that there is always something new to learn. Because of the decline of long-term employment, workers bear an ever-increasing portion of the risk that their skills will become obsolete and an ever-larger share of the costs of their training. ${ }^{+4}$ Why would an employer pay to train workers who will likely be working for someone else in a year or two?

The extensive amount of training necessary to obtain a job and cultivate one's career in the global economy interferes with the formation and growth of families in three ways. First, the period of initial training and cultivation has become so long that it intrudes into the prime relationship-forming and childbearing years. Although the bohemian life of a student can be fun, the transience and lack of resources of that period of life diminish a person's ability to form lasting relationships and bear children. Even once the student gets his or her initial job, most high-skilled and professional jobs now involve a period of "apprenticeship" filled with long hours, moves, and uncertainty. As the period of training and development extends from the early twenties into the late twenties and early thirties, it consumes more and more of the period of a person's life in which he or she has the psychological flexibility and energy to form lifetime bonds and raise children. Second, the growth in the period of training has also increased the

42. Cf. Browning, supra note 3, at 18; Whitehead Testimony, supra note 16, at 22 .

43. See Edgar, supra note 6, at 8. Cf. Waite \& Nielsen, supra note 7, at 24.

44. Dau-Schmidt, supra note 37, 13-14. 
period of child dependency and the costs of having and raising children. As expensive as child education was in the past, parents can look forward to even longer periods of support and larger tuition bills in the future if they want their children to have the skills necessary to succeed. This increase in the costs of childrearing will undoubtedly decrease people's desire for children. Finally, in the global economy, the risk that a worker's training will become obsolete and the costs of any necessary retraining fall disproportionately on the worker. The bearing of such risks and costs is inconsistent with investments in children, and workers in developed countries will adjust by having fewer children. ${ }^{45}$

Although both men and women suffer from the conflict between training and family formation in the global economy, the effects of this conflict in the paid labor market will be disproportionately borne by women. While women have achieved greater equality in the workplace throughout the developed world, they still provide a greater share of the childcare. ${ }^{46}$ As a result, women suffer a larger share of the conflict between career development and childbearing, including: forgone work experience and training; ${ }^{+7}$ the depreciation of skills during periods of childcare; ${ }^{48}$ and the undertaking of more flexible, but less remunerative, employment that will accommodate childcare. ${ }^{49}$ As women strive to gain jobs with flexible hours, men will be left to shoulder a disproportionate share of the inflexible jobs and lose opportunities to be with their families. Women also suffer from the fact that physically it is only possible or prudent for them to bear children into their forties, while men can father children at any age. Because of this "biological clock," encroachment of the training and career development years on the period of family formation and childbearing has a greater impact on a woman's opportunities to get married and have children than on a man's.

45. See Edgar, supra note 6, at 8; Hewlett, supra note 7, at 69.

46. See Gillian Lester, A Defense of Paid Family Leave, 28 Harv. J.L. \& Gender 1, 20 (2005), available at http:/www.law.harvard.edu/students/orgs/jlg/vol28/lester.pdf; Sharon Rabin Margalioth, Women, Careers, Babies: An Issue of Time or Timing?, 13 U.C.L.A. Women's L.J. 293, 308 (2005). While the women's liberation movement was successful in getting more women educated and into the paid workforce, marriage and children took a back seat. Margalioth, supra, at 307.

47. See Lester, supra note 46 , at $21-22$.

48. See id. at 22-23.

49. See id. at 23. On the other hand, men's response to the birth of children is to kick their career into higher gear so as to earn the resources necessary to raise the children. On average, women with children earn roughly 10 to $15 \%$ less than women without children whereas married menmostly with children-earn $10 \%$ to $15 \%$ more than unmarried men. See id. at 22 . 
Finally, highly educated and successful women will bear a disproportionate share of the conflict between career and family, even among women. The longer the commitment to training and career development required for a job, the bigger the conflict with family formation and childrearing. Traditionally, educated women have sought to marry men who were at least as accomplished as they were. ${ }^{50}$ Although this strategy was plausible when men were educated at higher rates than women, now that women are educated at higher rates than men, ${ }^{51}$ if educated women hold fast to this preference, it will mean that a disproportionate number of the unmarried women will be found among the highly educated. Lesser-educated women with ambitions for less demanding careers have advantages in pursuing highly educated men in that they can commit to a relationship earlier in their lives and offer less conflict in the man's future career choices. Even if educated women look for spouses among men with less demanding careers, the success of that strategy will depend on men accepting "more successful" wives. Studies have shown that the more educated and successful the woman, the more difficult it will be for her to find a marriage partner and have children. 52

\section{E. Children as a Public Good}

Some critics have argued that the care of children is a matter of purely private concern and should not be the responsibility of the state and its citizens. ${ }^{53}$ However, employers and the public at-large benefit from the investment in children as future, productive members of society. ${ }^{54}$ Employers need well-adjusted

50. Sylvia Ann Hewlett, Creating a Life: Professional Women and the Quest for ChilDREN 103 (2002).

51. In 1972, women accounted for only $9 \%$ of medical degrees, $1 \%$ of dental degrees, $7 \%$ of law degrees, and $8 \%$ of business degrees awarded, and by 1994 , women accounted for $38 \%, 38 \%, 43 \%$, and $47 \%$ of the medical, dental, law, and business degrees awarded, respectively. U.S. Dep't oF Educ., Achieving Success Under Title IX, in Trtre IX: 25 Years of Procress (1997), available at http://www.ed.gov/pubs/TitleIX/part4.html. But today, women earn the majority of bachelor's and master's degrees, $46 \%$ of doctorate degrees, and $48 \%$ of professional degrees. This trend is projected to continue through 2014. William J. Hussar, Nat'l Ctr. for Educ. Statistics, U.S. Dep't of Educ., Projections of Education Statistics to 2014, at 13 (2005), available at hetp:// nces.ed.gov/pubs2005/2005074.pdf.

52. See Margalioth, supra note 46, at 295, 300,307; Hewlett, supra note 7, at 68 . In the United States, for instance, $49 \%$ of female corporate executives earning at least $\$ 100,000$ per year are without children. Only $19 \%$ of their male counterparts are childless. Hewlett, supra note 50 , at 42.

53. See Lester, supra note 46 , at 43-44.

54. See id. at 45. 
and educated workers in order to make a profit. Similarly, the government, or society at-large, needs well-adjusted and educated citizens to pay taxes, vote in elections, serve on juries, serve in the military, and work for the government. ${ }^{55}$ The children's future tax payments may directly benefit other members of society through social insurance programs such as social security. "The role of care in the formation of human capabilities and in human development is fundamental. ${ }^{~}{ }^{6} \mathrm{Healthy}$ and better educated children will become good citizens and productive workers. ${ }^{57}$ Some philosophers, like Jean-Jacques Rousseau, believe that children are born innately good but that families must protect this goodness during the childhood years. ${ }^{58}$ Investment in education is one of the ways to protect this goodness and care for a child..$^{59}$

Because employers and other members of society enjoy some of the benefits of children, children and our investment in them are a "public good." ${ }^{60}$ In deciding whether to have children, and how much to invest in them, potential parents will take into account only their own costs and benefits from childrearing, and not the benefits of this activity for the larger society. Absent societal efforts to support childrearing and subsidize it to the extent of the benefits society reaps from this activity, potential parents will decide to have too few children and will not invest in those they do have to an efficient amount. ${ }^{61}$

\section{The Modern Family in the Global Economy}

There is growing evidence that the institution of the family is under stress in the developed world. The proportion of people that are married or in other committed, loving relationships is falling. Similarly, the number of children born is decreasing, especially within healthy, stable relationships. Finally, the amount of time that fathers and mothers are committing to paid labor, rather than childcare, is rising. On the whole, people in developed countries are investing less

55. Hewlett, supra note 7 , at 71.

56. UNDP REPORT, supra note 14 , at 77.

57. See Lester, supra note 46, at 19; see also Linda C. McClain, Care as a Public Value: Linking Responsibility, Resources, and Republicanism, 76 CHI.-Kent L. Rev. 1673, 1684 (2001).

58. Hilary Land, Children, Families, States, and Changing Citizenship, in The Blackwell Companion to the Sociology of Families, supra note 6, at 54, 58.

59. Cf. id.at 56.

60. UNDP REPORT, supra note 14 , at 80.

61. For a standard economic analysis of the public good problem, see HaL R. VARIan, INTERMEdiate Microeconomics: A Modern Approach 563-77 (1987). 
time and effort in the development of family relationships and the bearing and raising of children.

Not all of the observed change in the family in developed countries is a symptom of distress. The greater economic opportunities and success women have enjoyed in the developed world beginning in the 1970s allow women to avoid or escape bad relationships and pose an enticing alternative to the traditional female role of homemaker and mother. ${ }^{62}$ The greater availability of birth control since the 1970 s also allows people to exercise real choice in their decisions as to whether to have children and avoid unwanted pregnancies. Thus, the decline in marriage and birth rates, in part, reflects a general decline in the desirability of marriage and having children relative to other options, and a greater economic and physical ability, especially on the part of women, to order their personal lives as they see fit. ${ }^{63}$

However, it is apparent that not all of the decline in investment in family relationships and children is beneficial or desired. As discussed above, there are reasons to believe that people in developed countries will be constrained or encouraged to underinvest in family relationships and children in the new global economy. In most of these countries, the birth rate has fallen below the replacement rate, imperiling social welfare programs based on intergenerational support. ${ }^{64}$ Moreover, survey results suggest that people in developed countries would like to have more family relationships and children than they have, and to spend more time with their children. In attempting to strike the balance between family and career in the new global economy, many people are finding that the scales are balanced against the family.

\section{A. The Decline of Marriage and Other Committed Relationships}

Individuals are getting married later and less frequently than they were thirty years ago. As the period of education and training necessary to secure a job grows longer, many people are postponing the marriage decision, which sometimes means foregoing it entirely. It is often easier for two people to arrange to live together in marriage if they plan their life together when they are young.

62. See Megan M. Sweeney, Two Decades of Family Change: The Shifting Economic Foundations of Marriage, 67 Ам. Soc. Rev. 132, 133-34 (2002); see also Diane K. McLaughlin \& Daniel T. Lichter, Poverty and the Marital Behavior of Young Women, 59 J. MARriage \& FAM. 582, 583 (1997).

63. The decline in the birth rate can also, of course, yield great benefits for the environment.

64. See Longman, supra note 23 , at $66,68-69$. 
When couples do marry, the average age at the first marriage is steadily increasing. ${ }^{65}$ In France, the mean age for the first marriage for women increased from 23 to 29.1 in the period from 1980 to $1999 .{ }^{66}$ Even in Japan, where the culture has traditionally expected women to marry in their twenties, the couple's age at the first marriage has increased. ${ }^{67}$

In almost all industrialized countries, marriage rates are dropping while divorce rates are steady or even increasing. ${ }^{68} \mathrm{Graph} 1^{69}$ presents marriage rates for five industrialized nations: the United States, Germany, France, the United Kingdom, and Japan. Examining this data, we see that the annual marriage rate per thousand in the United States has dropped from 15.9 in 1980 to 12.8 in 2000. The United Kingdom has suffered a similar decline from 11.6 in 1980 to 7.8 in 2000. Only Japan exhibits oscillation in its marriage rate, and it too has experienced declines over the last fifty years. ${ }^{70}$ Of course, cohabitation rates have risen during the same period, in some countries dramatically so, ${ }^{71}$ and the romantics among us might hope that people can still find a life partner even if it is without the benefit of marriage. However, data from the industrialized countries that include all cohabiting couples, whether married or not, in their population surveys are not encouraging in this regard. ${ }^{72}$ As presented in Graph $2,{ }^{73}$ all of the countries, including Canada, Denmark, Ireland, France, the Netherlands, and Sweden, show that the percent of cohabiting couples, as a percent of a country's population, has steadily declined over the last twenty-five years, despite a general aging of the population.

65. See Martin \& Kats, supra note 1 , at 9 chart 1.

66. Id.

67. See Tsuya \& Bumpass, supra note 5, at 6; Norimitsu Onishi, At 35, a Princess Decides the Time is Right to Marry, N.Y. TIMEs, Dec. 6, 2004, at A4.

68. See Martin \& Kats, supra note 1 , at 8 tbl.3.

69. Id.

70. Statistics Bureau, Ministry of Internal Affairs and Commc'ns, Japan, Statistical Handbook of Japan: 2005, at 17 fig.2.7 (2005) [hereinafter Statistical Handbook of Japan], available at http:/www.stat.go.jp/english/data/handbook/pdf/c02cont.pdf.

71. See Browning, supra note 3, at 15. In Sweden, for instance, by the end of the 20th century, $70 \%$ of all couples between the ages of 16 and 29 were cohabitating. Martin $\&$ Kats, supra note 1, at 11 .

72. See Martin \& Kats, supra note 1, at 12 tbl.5.

73. Id. Due to variations in timing of census and survey data, some substitution of data was necessary. Substitute data were selected from the nearest available period, as follows: Canada-1981, 1991, and 2001; Denmark-2001; Ireland-1991, 2002; France-1982; Netherlands-1988; Sweden1985 (for 1980). 
Graph 1: Marriage Rates in Selected Countries: 1980-2000

(Marriage rate per 1,000 people aged $15-64$ per year)

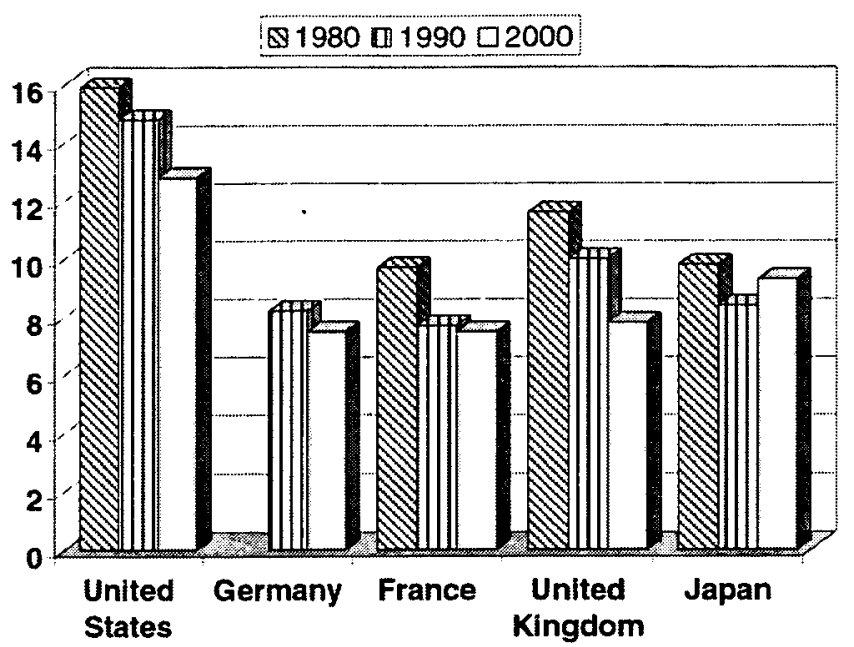

Graph 2: Percent of Cohabiting Households, Married and Unmarried: 1980-2000

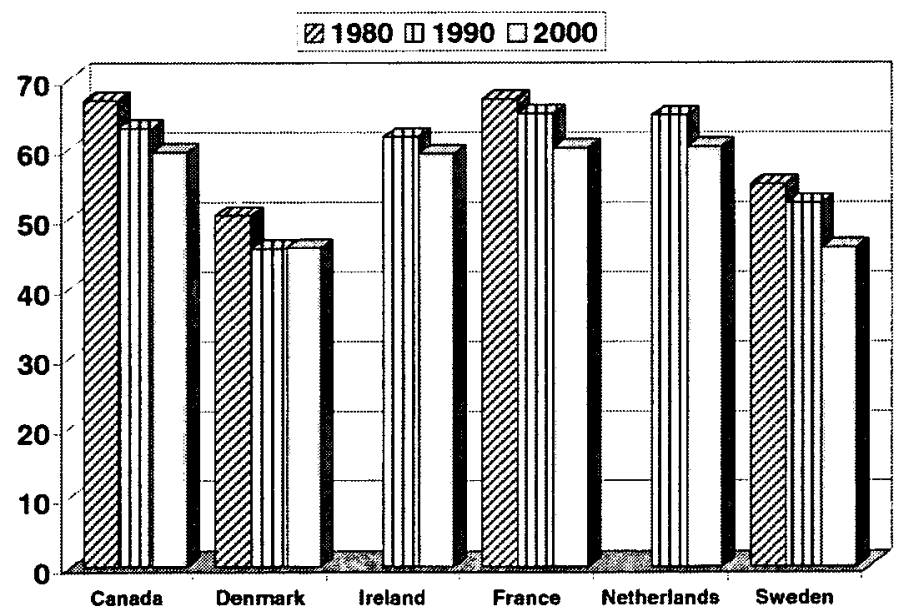

Although people are coupling less, they still have the desire to marry. In the United States, for instance, roughly 90 percent of single men and women between the ages of twenty and twenty-seven would like to marry, while in Japan, 80 percent of young singles would like to marry. ${ }^{74}$ In another study examining 
marriage and children preferences of Japanese and American men and women between the ages of twenty-five and fifty-nine, marriage and having children were deemed important to achieve personal happiness and fulfillment, but more so in Japan than in the United States. ${ }^{75}$ Marriage and children were found to be more important in the older age groups-as well as for men in general. ${ }^{76}$

\section{B. Decreasing Birth and Fertility Rates}

Declining birth rates and fertility rates have become endemic to the developed world. ${ }^{77}$ As a result of later and fewer marriages, the age of mothers at first birth is also increasing. ${ }^{78}$ In France, the mean age at first birth for women has risen from 25 to 28.7 over the years 1980 to 1999, and in Spain, the mean age at first birth for women has risen from 25 to 29 over the same period. ${ }^{79}$ Because fewer women are getting married and because they are having children later, women have fewer childbearing years, leading to a significant decline in birth rates. ${ }^{80}$ Data on birth rates for the United States, Germany, France, the United Kingdom, and Japan are set forth in Graph $3{ }^{81}$ The data show a significant decline in the birth rate in each of these countries over the period 1970 to 2001 , ranging from a decline of 8.9 births per thousand in Japan over this time period, to a decline of 3.9 births per thousand in France. The decline in Japan's birth rate over the years 1970 to 2000 is larger than the current birth rate in Germany.

75. See id. at 22-25 figs.2.1-2.4.

76. See id.

77. Longman, supra note 23 , at 64-65.

78. See Martin \& Kats, supra note 1 , at 9 chart 1 . For instance, the mean age of women at first birth increased from 23 years in 1980 to 24.5 years in 1999.

79. See Martin \& Kats, supra note 1, at 9 chart 1.

80. See Infoplease, Crude Birth and Death Rates for Selected Countries, http://www.infoplease. $\mathrm{com} / \mathrm{ipa} / \mathrm{A} 0004395 . \mathrm{html}$ (last visited Sept. 29, 2005).

81. Infoplease, Live Births and Bith Rates, By Year, http:/www.infoplease.com/ipa/A0005067.html (data for United States-1970); U.S. Census Bureau, Int'l Database (data for United States-1980, 1990, 2000, and 2001), http:/www.census.gov/ipc/www/idbprint.heml (select table "008 Vital Rates," select country "United States," select "All Available Years," click "Submit Query" button); Council of Eur., Recent Demographic Developments in Europe: 2003, at 65 tbl.3.1 (2003) (data for Germany, France, and the United Kingdom), available at http:/www.coe.int/de/social_ cohesion/population/Demographic\%20Year\%20Book\%202003\%20EN.PDF; Statistics Bureau, Ministry of Internal Affairs and Commc'ns, Japan, Statistical Handbook of Japan: 2005, at 14 tbl.2.4 (2005) [hereinafter Statistical Handbook of JAPAN] (data for Japan), available at http:/l www.stat.go.jp/english/data/handbook/pdf/c02cont.pdf. 
Graph 3: Birth Rates in Selected Industrialized Countries: 1970-2001

(Live Births per 1000 Women Aged 15-50)

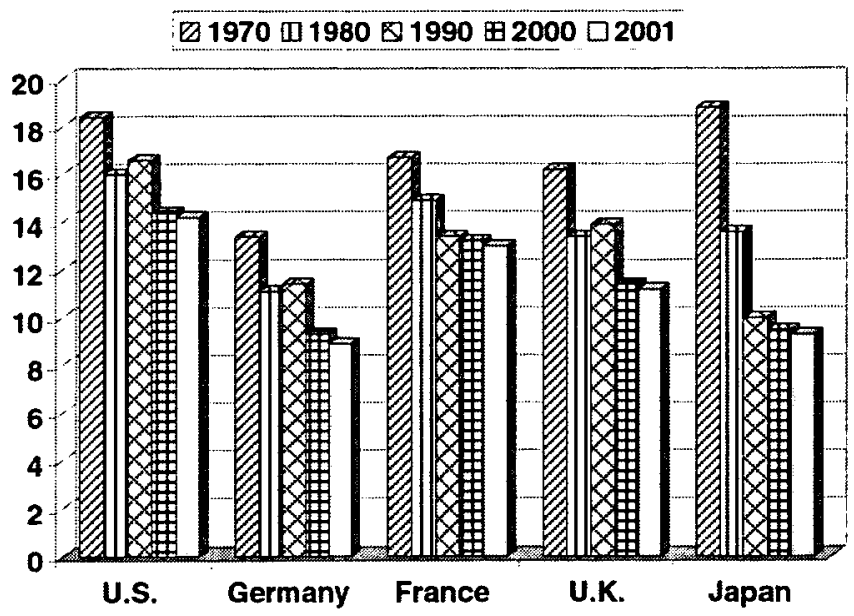

In most developed countries, fertility rates have dropped below the replacement level of 2.1 births per woman over her lifetime necessary to maintain current population levels. ${ }^{82}$ The United States, with a fertility rate of 2.05 children per woman, has not suffered as significant a decrease as Japan and most European countries because immigration has kept the U.S. population growing. ${ }^{83}$ EU Member States have experienced large decreases in fertility rates since 1965, when all Member States had rates above 2.0 children per woman. ${ }^{84}$ By 2000 , the average fertility rate for Europe had fallen to 1.48 children per woman. ${ }^{85}$ There is generally an inverse relationship between fertility rates and women's participation in the work-

82. See Longman, supra note 23, at 66-67. See also Martin \& Kats, supra note 1, at 4 tbl.1. The fertility rate for a given country for a given year is the mean number of children that would be born alive to a woman during her lifetime if she were to pass through her childbearing conforming to the fertility rates, by age, of that year. Due to deaths after birth, it is generally estimated that the fertility rate that is necessary in a developed country for the population to maintain a steady level is 2.1 live births per woman. Martin \& Kats, supra note 1, at 4.

83. See Michael Specter, Population Implosion Worries a Graying Europe, N.Y. Times, July 10, 1998 , at A1.

84. Joris Ghysels, Work, Family and Childcare: An Empirical Analysis of European HOUSEHOLDS 43 (2004).

85. Linda Hantrais, Family Policy Matters: Responding to Family Change in Europe 20 tbl.2.1 (2004). The EU rates reflect only those for the $15 \mathrm{EU}$ member states prior to the $2004 \mathrm{en}$ largement: Austria, Belgium, Denmark, Finland, France, Germany, Greece, Ireland, Italy, Luxembourg, the Netherlands, Portugal, Spain, Sweden, and the United Kingdom. 
force; however, France has one of the highest percentages of women in the workforce, yet it also has one of the highest fertility rates in Europe, though still well below the replacement level. ${ }^{86}$ France has been able to slow the rapid decline in fertility rates by offering substantial state family services, including childcare, and by encouraging a more balanced sharing of family responsibilities between fathers and mothers with paid paternity leave ${ }^{87}$ In Japan, the fertility rate in 1970 was 2.07 children per woman; by 2000 , that number had fallen to $1.41 .^{88}$ The rapid decline in Japan has been attributed to the rising childcare costs and the delay in marriage. ${ }^{89}$ Even in Ireland, traditionally one of the most fertile countries of Europe, the fertility rate has dropped below the replacement rate. ${ }^{90}$ The fertility rates of five representative developed countries over the years 1960-2002 are set out in Graph 4.91

Despite the decrease in birth and fertility rates, people in developed countries still desire children, although in some countries they desire a smaller number of children. In the United States, a 2003 survey of childless couples ages forty-one and older showed that 76 percent wished they had had children, up six percentage points from a 1990 survey." "Women reported that being childless was not a conscious choice for them, but rather a 'creeping nonchoice,' meaning that circumstances, usually career-oriented, dictated the childless path of their personal lives." ${ }^{33}$ Even among extremely successful business and professional women ages forty-one to fifty-five earning more than $\$ 100,000$ per year, 31 percent still desire children. ${ }^{94}$

Some surveys have focused on the preferred number of children. In 2000, European and American women forty years of age and older stated that they

86. See Fine-Davis ET Al., supra note 20, at 78-79. Italy, on the other hand, has one of the lowest fertility rates and a low participation rate of women in the workforce. Id. at 79 .

87. See id. at 79-80.

88. Hantrais, supra note 85 , at 20 tbl.2.1.

89. See Tsuya \& Bumpass, supra note 5, at 6; Tsuya \& Kim Choe, supra note 24 , at 76.

90. See Fine-Davis ET AL, supra note 20, at 78, 79 tbl.6.4. The fertility rate in Ireland plummeted from 3.3 in 1980 to 1.98 in 2001. Id. at 79 tbl.6.4.

91. U.S. Census Bureau, Int'l Database (data for United States), http://www.census.gov/ipd www/idbprint.html (select table "028 Age-Specific Fertility Rates and Selected Derived Measures," select country "United States," select "All Available Years," click "Submit Query" button); Council of Eur., supra note 81, at 70 tbl.3.3 (data for European countries); Statistical HandBOOK OF JAPAN, supra note 81 , at 14 tbl.2.4 (data for Japan).

92. See Longman, supra note 23 , at 77.

93. Margalioth, supra note 46, at 306-07; see also HewLETT, supra note 50 , at 3.

94. Hewlett, supra note 50 , at 86-87. 
Graph 4: Fertility Rates for Selected Countries: 1960-2002

(2.1 = Replacement Rate)

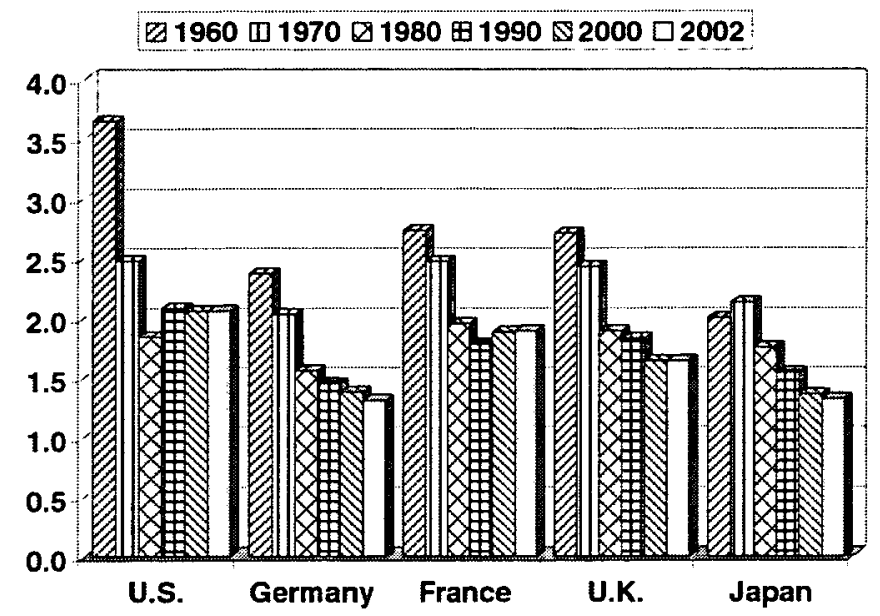

had produced fewer children than they would have liked..$^{5}$ In fact, had the women produced the number of children desired, fertility rates in Europe and the United States would be above the 2.1 replacement rate. ${ }^{96}$ In Sweden, there is no suggestion that people prefer to have just one child; rather, people are starting their families later. ${ }^{97}$ In Italy and Spain, where fertility rates are lowest, however, people do prefer to have only one child, despite the fact that the Italians and Spanish place more importance on having children than most northern Europeans. ${ }^{98}$ Regardless of what individuals may wish or want, collected data indicate that birth rates are declining throughout the developed world.

95. See Longman, supra note 23, at 77. Even among extremely successful American business women who had children, $24 \%$ indicated that they had fewer than they wanted. Hewlett, supra note 50 , at 86 .

96. See Longman, supra note 23, at 77. In France, there is some evidence that parents would like to have 3 or more children but fewer than $20 \%$ do. Recent French family legislation might help boost this percentage over the next few years. See Charles Bremner, Middle Class Offered Baby Bonus, Times (London), Sept. 23, 2005, available at http://timesonline.co.uk/printFriendly/ 0,,1-13090-1793524-13090,00.htm.

97. See Laura den Dulk, Work-Family Arrangements in Organisations: A Cross-National Study in the Netherlands, Italy, the United Kingdom and Sweden 23 (2001).

98. See id. at 24; Kathleen Kiernan, Changing European Families: Trends and lssues, in THE Blackwell Companion to the Sociology of Families, supra note 6, at 17, 23. 


\section{Increasing Paid Workforce Participation by Parents}

Families are spending more time in the paid labor market and less time raising children. ${ }^{99}$ Among males in the United States, Europe, and Japan, current participation in the labor force is between 70 and 80 percent. ${ }^{100}$ Although men's participation level has declined slightly since the $1970 \mathrm{~s},{ }^{101}$ women's participation rate has drastically increased. ${ }^{102}$ In $2003,57.5$ percent of U. S. women were in the paid labor force, up from 42.2 percent in $1973,{ }^{103}$ while 54 percent of European women worked outside of the home in 2001 , up from 45 percent in $1985 . .^{104} \mathrm{~A}$ lthough female participation rates have been fairly consistent in Japan since World War II, today Japanese women spend more time in the paid workforce rather than in family enterprises. ${ }^{105}$ Expanded educational opportunities have been instrumental in the changing roles of women at work and home. ${ }^{106}$ Increasingly, married women and mothers are staying in the workforce longer, ultimately affecting the number of children families have. ${ }^{107}$ Moreover, an increasing number of these working women are of childbearing age, ${ }^{108}$ resulting in an increased demand for alternative work arrangements, childcare, and workforce equality. ${ }^{109}$

99. See Lawrence Mishel et al., The State of Working America: 2004/2005, at 100 (2005). 100. See id. at 250 tbl.3.9 (U.S. employment rates by gender); Fine-Davis et AL., supra note 20, at 76 tbl.6.1 (2000 European labor force participation rates by gender); NAt'L Inst. of Population and Soc. Sec. Research, Population Statistics of Japan 103 tbl.8.2 (2003) |hereinafter PopulaTION Statistics of JAPAN] (labor force participation rates for Japan by gender), available at http:/ www.ipss.go.jp/p-info/e/psj2003/PSJ2003.pdf.

101. See Mishel et al., supra note 99, at 250 tbl.3.9 (U.S. labor participation rates); Population Statistics of Japan, supra note 100, at 103 tbl.8.2. Ghysels, supra note 84, at 46 fig.2.5 (European labor participation rates). European scholars argue that increased educational opportunities and an aging population have contributed to this decline. See id. at 47.

102. See Mishel et al., supra note 99, at 250 tbl.3.9 (U.S. labor participation rates); Ghysels, supra note 84 , at 46 fig. 2.5 (European labor participation rates). In Japan, women's labor participation has slightly decreased. See Population Statistics of Japan, supra note 100, at 103 tbl.8.2.

103. Mishel et AL., supra note 99 , at 250 tbl.3.9.

104. See Fine-Davis Et al., supra note 20, at 75; Hantrais, supra note 85 , at 89 tbl.4.2.

105. In Japan, $48.2 \%$ of the female population was in the workforce in 2000 , up from $46.9 \%$ in 1980 , yet down more than two and one-half points from 1960. Population Statistics of Japan, supra note 100 , at 103 tbl.8.2.

106. See Tsuya \& Bumpass, supra note 5 , at 10.

107. See Hantrais, supra note 85, at 92-93; GHysels, supra note 84, at 37.

108. See Tsuya \& Bumpass, supra note 5 , at 10.

109. Fine-Davis et al., supra note 20, at 1. 
The annual number of hours worked in the paid labor force by families with children has grown substantially through the increased participation by women. ${ }^{110}$ Since 1975 , the average number of hours spent by families in the paid workforce has increased 11 percent. ${ }^{11}$ One-career families in the United States spend 72.3 hours per week in the workforce compared to only 57.4 hours spent by similar families in the United Kingdom, while two-career families in the United States spend 81.2 hours working, longer than other two-career households in similar countries. ${ }^{12}$ Indeed, U.S. workers, on average, spend more time in the paid labor force than workers in any other country in the Organisation for Economic Co-operation and Development (OECD), except Australia. ${ }^{113}$ Most Americans would like to work fewer hours, but either they cannot afford to reduce their hours or their employers do not offer part-time or other flexible working arrangements. ${ }^{114}$

Despite the increase in time spent in the labor market, families are not getting much for their labor. ${ }^{115}$ There have only been modest increases in family income since 1979, and any growth has been unequally distributed among the classes. In the United States, real income for the lowest one-fifth of earners grew only 6.4 percent from 1979 to 2000 , while income for the top one-fifth grew 70 percent and 185 percent for the top 1 percent of earners. ${ }^{116}$ In the global economy, people of modest means have had to supply more labor and spend less time with their children just to maintain their standard of living, yet they end up further behind their wealthier neighbors. Our purpose in this essay should not be misunderstood as a criticism of women working outside the home. Women's achievements in the paid labor market, as elsewhere in society, are to be enjoyed and celebrated. Our only point is that if people's careers require excessive hours in paid employment, family life and childrearing will suffer. The number of

110. Mishel ET AL., supra note 99, at 100, 101 fig.1S (growth of average annual family work hours), 102 tbl.1.26 (annual hours worked by families with children).

111. See id at 100-01.

112. Schultz \& Hoffman, supra note 31 , at 5.

113. Mishel et al., supia note 99 , at 415 tbl.7.18.

114. Schultz \& Hoffman, supra note 31 , at 6.

115. See Lawrence Mishel \& David M. Frankel, The State of Working America 69-71 (199091 ed. 1991); McCluskey, supra note 8, at 132.

116. Mishel Et Al., supra note 99 , at 39. 
hours a person works can contribute to the breakup of a family ${ }^{117}$ and have a detrimental effect on children's emotional and mental development. ${ }^{118}$

\section{Solving the Problem of Underinvestment in Families}

Parents, the community, the market, and the government can each play an important role in addressing the problem of the underinvestment in families in developed countries. Society no longer can, or should, rely on the subjugation of women as a means of ensuring that people have adequate mobility in the labor market to form families while responding to the demands of a career and that adequate time and resources are dedicated to the rearing and education of children. ${ }^{119}$ Instead, the disruption to families and the underinvestment in children must be mitigated through market and government responses. We now examine what some of those responses might be. Historically, the United States and the United Kingdom have generally relied on the market to address family needs, ${ }^{120}$ while continental European countries, and Japan to a lesser extent, have relied on governmental programs.

\section{A. Market Responses and Remedies}

In the United States, the primary method for workers to address their needs in the employment relationship has always been through individual negotiations and

117. See John H. Johnson, Do Long Work Hours Contribute to Divorce?, 4 Topics Econ. Analysis \& PoL'y art. 24, at 12, 15 (2004). This is perhaps because the fewer hours a woman works in the paid workforce, the more she must rely on her husband for economic support. Id. at 12.

118. See O'Connor-Felman, supra note 28, at 1311. However, a child of divorced parents may be better off than a child living with both parents in a home with significant turmoil. See Stephen J. Bahr, Social Science Research on Family Dissolution: What It Shows and How It Might Be of Interest to Family Law Reformers, 4 J.L. \& Fam. Stud. 5, 10-11 (2002).

119. "Mothers create human and social capital-the next generation, workers with human and social skills who can be relied on, who are good citizens. But mothers cannot demand a fee from employers who hire their children. This care will be underproduced and overexploited unless non-market institutions ensure that everyone shares the burden of providing it. The traditional patriarchal family, and gender biases that limit opportunities for women outside the role of wife and mother, have been the traditional way to solve this problem. But this is obviously inequitable, and no solution at all." UNDP REPORT, supra note 14, at 80 .

120. See den Dulk, supra note 97, at 41, 44; Cynthia H. Deitch \& Matt L. Huffman, FamilyResponsive Benefits and the Two-Tiered Labor Market, in Working Families: The Transformation of the American Home, supra note 7, at 103. 
contract. ${ }^{121}$ In comparison with other countries, this has produced some "harsh" results for employees in the United States because our law governing individual employment contracts has emphasized "freedom of contract" and flexibility with respect to the agreements employers can negotiate with individual employees. ${ }^{122}$ Individual bargaining can provide the most personalized solution for meeting the needs of the parties. It also enjoys relatively low administrative costs. Unfortunately, market failures and lack of bargaining power ${ }^{123}$ mean that individual bargaining often results in uneven benefits and an impoverished solution for many workers that fails to address many of their basic needs. ${ }^{124}$ Although there have been several successful individual market-driven programs, overall the market response to our current family problems in the United States has been inadequate. ${ }^{125}$

\section{Private Employee Benefits}

There are two key areas under the control of the employer that substantially affect the family: the hours of work and the provision of on-site childcare.

\section{a. Alternative Work Arrangements}

Alternative work arrangements provide flexible options to the traditional work schedule, enabling parents to better accommodate both professional and

121. Kenneth G. Dau-Schmidt \& Carmen L. Brun, United States of America (Individual Bargaining, Collective Bargaining and Protective Legislation: Determining the Terms and Conditions of Employment in America), 53 Bull. Comp. Lab. Rel. 183 (2004) (the "American Paper" in an international conference on "The Mechanisms for Establishing and Changing Terms and Conditions of Employment" hosted by the Japan Institute for Labour Policy and Training). An employment contract can be either express or implied and is not required to be in writing. Alvin $L$. Goldman, Labor and Employment Law in the United States 58 (1996).

122. Dau-Schmidt \& Brun, supra note 121. State courts have often struck down "labor protective legislation on freedom of contract grounds." Matthew W. Finkin et al., Legal Protection for THE INDividual EMpLOYeE 22 (3d ed. 2002).

123. Dau-Schmidt \& Brun, supra note 121, at 183-84. See Kenneth G. Dau-Schmidt, Meeting the Demands of Workers into the Twenty-First Century: The Future of Labor and Employment Law, 68 IND. L. J. 685, 688-92 (1993). Market failures include imperfect information, imperfect processing of information, and public goods. For instance, an individual is unable to bargain for public goods, such as the air quality and lighting at the workplace, because improvement of these goods enjoyed by one worker cannot be to the exclusion of the other workers. Id. at 690 .

124. Dau-Schmidt \& Brun, supra note 121, at 183. The market creates uneven benefits. The family-work conflict is greater for lower-income families because higher-income working parents tend to hold managerial positions with greater bargaining power and more comprehensive family benefits. Higher-income families also have greater access to financial resources and job opportunities. See Deitch \& Huffman, supra note 120, at 103-04.

125. $C f$. Lester, supra note 46 , at 10. 
personal responsibilities. Men and women agree that one of the best ways to balance both professional and personal obligations is to give the employee more control over the hours worked. ${ }^{126}$ While part-time employment is popular in the general population, there are other options that do not require a reduction in overall hours. Job-sharing, flex-time, compressed scheduling, and telecommuting are viable alternatives that permit the employee to work full-time, yet maintain his or her personal responsibilities. ${ }^{127}$

In Europe, part-time employment was originally used to reduce unemployment and increase the number of jobs available. Instead, it has provided some much needed flexibility for parents to balance family and work. ${ }^{128}$ Much of the increase among women in the European work force has been through part-time employment. ${ }^{129}$ Although men do work part-time, it is still primarily used by women to accommodate family responsibilities. ${ }^{130}$ Moreover, the more children a woman has, the more likely she is to work part-time if she stays in the paid workforce. ${ }^{131}$ Men are less likely to ask for a flexible schedule because of societal mores. It is not as socially acceptable for men to put family values ahead of work. ${ }^{132}$ For instance, in the high-powered U.S. legal profession that requires long hours of all workers, 44 percent of the male attorneys surveyed say it is unacceptable for a man to work a reduced schedule, ${ }^{133}$ yet an estimated 71 percent of men with children experience difficulty in balancing professional and personal responsibilities. ${ }^{134}$

126. Catalyst, A Career in the Law: A Guide For Women Law Students 8 (NALP ed., 2001). 127. See Judith N. Collins, Findings from the NALP Workplace Questionnaire, NALP BuLl., Oct. 2005, available at http://www.nalp.org/assets/library/345_1005wqresearch.pdf; DEN DuLk, supra note 97, at 8 . 128. See Peter Berg et al., Contesting Time: International Comparisons of Employee Control of Working Time, 57 Indus. \& Lab. Rel. Rev. 331,339 (2004).

129. Shirley Dex, Work and Families, in The Blackwell Companion to the Sociology of FamILIES, supra note 6, at 435, 436; Martin \& Kats, supra note 1, at 19-21, 21 tbl.12.

130. In the United States, $68.1 \%$ of all part-time jobs are held by women. More than $75 \%$ of all part-time jobs in Ireland, the Netherlands, Spain, Sweden, and the United Kingdom are held by women, while in France and Germany, women comprise more than $80 \%$ of all part-time workers. Martin \& Kats, supra note 1, at 22 tbl.13.

131. See Christel Aliaga, Gender Gaps in the Reconciliation Between Work and Family Life, Stat. Focus (Eurostat), Apr. 2005, at 3, available at http://epp.eurostat.cec.eu.int/cache/ITY_OFFPUB/ KS-NK-05-004/EN/KS-NK-05-004-EN.PDF.

132. See Keith Cunningham, Note, Father Time: Flexible Work Arrangements and the Law Firm's Failure of the Family, 53 Stan. L. Rev. 967, 977 (2001).

133. Id. at 993.

134. Catalyst, Women in Law: Making the Case 18 (2001) ("In particular, 71 percent of both men and women law graduates with children report work/life conflict. ... Men and women law graduates cite the same sources of that conflict in almost the same numbers."). 
In the fifteen pre-accession EU countries, 33 percent of women work parttime compared to only 6 percent of men. ${ }^{135}$ In the United States, 14.6 percent of women work part-time, while in Japan, 38.4 percent of women choose to work part-time. ${ }^{136}$ Unfortunately, part-time employment is not perceived as an equally viable employment option throughout the developed world. Part-time workers generally receive less pay, reduced or nonexistent health and leave benefits, decreased job security, inferior working conditions, and reduced chances for promotion. ${ }^{137}$ Furthermore, part-time workers, especially in the United States, are often perceived as less committed to the workplace. ${ }^{138}$ In truth, an employee who takes advantage of an alternative work schedule and, as a result, leads a more balanced life, is often more committed to the employer than his or her colleagues. ${ }^{139}$

A company accrues several benefits by offering alternative work arrangements to its employees. Flexible work schedules help to improve the organization's image, boost employee morale and motivation, reduce employee absenteeism, increase employee happiness and loyalty, and in the case of telecommuting, reduce company overhead. ${ }^{140}$ Alternative work arrangements also increase employee retention, which in turn reduces hiring and training costs. ${ }^{141}$ Deloitte and Touche, an organization providing professional services worldwide, estimates that it saved fourteen million dollars per year by adopting alternative work schedules. ${ }^{142}$ Moreover, promoting alternative work schedules can allow people to have families and stay in the workforce, saving society's investment in their training. Currently, 22 percent of women with advanced education have left the paid workforce. "What an extraordinary waste of expensively educated talent!"143

135. Berg et al., supra note 128 , at 339 .

136. Martin \& Kats, supra note 1, at 22 tbl.14.

137. See Mishel et Al., supra note 99, at 256; Grysels, supra note 84, at 48; Hiroyuki Ida, PartTime Work in Japan-An Approach to Explain the Inferior Status of Part-Time Workers, in WoMEN IN Japan and Sweden: Work and Family in Two Welfare Regimes 93, 93 (Carl le Grand \& Toshiko Tsukaguchi-le Grand eds., 2003).

138. See Cunningham, supra note 132, at 983.

139. See id. at 984; Catalyst, supra note 134, at 43.

140. See Fine-Davis et al., supra note 20, at 242; Den Dulk, supra note 97, at 52-53.

141. Martha W. Barnett, Women Practicing Law: Changes in Attitudes, Changes in Platitudes, 42 Fla. L. Rev. 209, 222 (1990); see also Cunningham, supra note 132, at 1003.

142. Symposium, Unbending Gender: Why Family and Work Conflict and What To Do About It, 49 Aм. U. L. Rev. 851, 856 (2000).

143. Hewlett, supra note 7 , at 71 . 
If parents are to be encouraged to have more children or spend more time investing in their children, businesses must ensure that the benefits and working conditions for alternative work arrangements are commensurate with those of full-time positions. Employees who take advantage of flexible work arrangements should not be treated by employers as second-class citizens. Upper management must fully support alternative work arrangements and create a corporate culture that encourages employees to balance work and family. Indeed, a family-friendly culture should include the election by shareholders of more working mothers to corporate board positions. ${ }^{1+4}$

\section{b. Employer Childcare Facilities}

There are several ways in which an employer may assist employee-parents with childcare arrangements. Employers may open their own on-site facility, contract with a local childcare center, or subsidize part of the employee's off-site childcare costs. ${ }^{145}$ Employers may also develop special daycare programs during breaks and vacations to assist parents when schools are closed. ${ }^{146}$ Childcare arrangements provided by the employer are not widely available. Organizations generally find that the alternative work arrangements discussed above are less expensive than childcare arrangements, and the provision of childcare facilities, if available, seldom affects the employee's work and timing of the work. ${ }^{147}$ Seventy percent of large and medium-sized corporations in the Netherlands have childcare arrangements, while in Italy, the United Kingdom, and Sweden, only 11 percent, 27 percent, and 2 percent of corporations, respectively, provide for childcare. ${ }^{148}$ In Sweden, however, the government provides substantial childcare benefits to families; thus, corporate-sponsored daycare is not as instrumental to the employees. ${ }^{149}$

\section{c. Other Policies Private Employers Could Undertake to Support} Families

Sylvia Ann Hewlett, founder and chairman of the National Parenting Association, has performed extensive research on the challenges women face bal-

144. O'Connor-Felman, supra note 28, at 1349.

145. Den Dulk, supra note 97, at 10, 125.

146. Id. at 10 .

147. Id. at 7 .

148. Id. at 125.

149. Id. Government childcare programs are discussed infra Part IV.B. 
ancing work and family. ${ }^{150}$ Hewlett has proposed several employer policies that would help to reduce the work-family conflict suffered by many employees. Employers should offer employees the option of taking an extended unpaid leave of absence for up to three years with the guarantee of the same or a similar job upon return. ${ }^{151}$ Although in the United States the current statutorily imposed requirements of the Family and Medical Leave Act (FMLA) do guarantee the employee a job upon return, the employee is only entitled to twelve weeks of unpaid leave per year, and the purpose of the absence must fall within one of the federally approved categories. ${ }^{152}$

Employers should also develop upper-management jobs that allow a permanent reduction in hours and workload, yet still keep the employee on a promotion track. ${ }^{153}$ As will be discussed below, the French government established a reduced-hour workweek for the majority of French workers; however, the plan was largely a failure. ${ }^{154}$ Rather than requiring all positions and employees to be subject to reduced hours, certain employer-created positions with reduced hours and workload would provide much-needed flexibility to those employees who needed it and yet still allow the employer to meet its workload requirements.

Finally, employers should offer paid parental leave of up to six months that a parent can take in any increment anytime before the child turns eighteen. ${ }^{155}$ Because employers reap the future economic benefits of healthy, well-nurtured children, a six-month paid absence is a minimal investment. Furthermore, employees who are able to better balance work and family and receive some remuneration for the caring of their children will be happier and more loyal to their companies. As will be discussed below, paid parental leave is a statutory entitlement in several European countries.

150. See generally Hewlett, supra note 7, at 66; Hewlett, supra note 50; Taking Parenting Public: The Case for a New Social Movement (Sylvia Ann Hewlett et al. eds., 2002); Sylvia AnN Hewlett \& Cornel West, The War Against Parents: What We Can Do for America's Beleaguered Moms and Dads (1998); Sylvia Ann Hewlett, Child Neglect in Rich Nations (1993); Sylvia Ann Hewlett, A Lesser Life: The Myth of Women's Liberation in America (1987).

151. Hewlett, supra note 7, at 72.

152. See 29 U.S.C. $\$ 2612$ (2005).

153. See Hewlett, supra note 7, at 72; Hewletr, supra note 50, at 282-83.

154. After France virtually dismantled the 35-hour workweek legislation, French President Jacques Chirac called the policy an "historic error that crippled the competitiveness of the French economy." 35-hour Working Week a Dismal Failure, Dally Telegraph (Austl.), Mar. 24, 2005, at 32. 155. HewLetT, supra note 50, at 281-82. 


\section{Housework-Saving Devices and Private Services}

The market has responded to the changing workforce and family in other respects. With the family spending more hours in the paid workforce, time previously devoted to household chores is at a premium. The market, especially in the United States, has responded with an explosion of services and goods specifically targeted to the busy family. Grocery stores, pharmacies, and discount department store chains, such as Wal-Mart and Target, are frequently open twenty-four hours a day. ${ }^{156}$ Fast-food restaurants with either convenient drivethru windows or home-delivery service provide quick meals for families on the run. Frozen and prepackaged foods, while heavily consumed in the United States, are also growing in popularity in Europe. ${ }^{157}$ Even in France where unhurried, gourmet meals were traditionally the norm for families, convenience foods and fast-food restaurants are assaulting the market. In 1978, the average French meal lasted nearly one and a half hours. Today, the average French meal is consumed in thirty-eight minutes. ${ }^{158}$

Household responsibilities, including housework and childcare, have also been relegated to the market as more women entered the labor force. ${ }^{159}$ While labor-saving devices like washing machines, microwave ovens, and dishwashers have reduced the amount of labor spent cooking and cleaning, the devices have not saved much time. Instead, the devices have encouraged people to increase standards for cleanliness and cooking, thus mitigating any potential time savings. ${ }^{160}$

156. We are moving to a 24 -hour society, especially considering that more than $20 \%$ of employees spend some time between 7 p.m. and 7 a.m. at work. Hugh Wilson, The Power of Darkness, THE Guardian (London), Mar. 15, 2005, at 8, available at http:/www.guardian.co.uk/g2/story/ $0,1437865,00 . \mathrm{html}$. "This is the age of the consumer. . . The age of the consumer . . means shopping 24 hours a day." Tracie Rozhon, No Longer Belles of the Mall, Department Stores Try Makeovers, N.Y. Times, Mar. 1, 2005, at C1.

157. In the United Kingdom, the retail frozen-food market is now a $£ 4$ billion industry while the foodservice frozen-food market is roughly $£ 3$ billion per year. See British Frozen Food Fed'n, Market Dynamics for Frozen Foods, Apr. 2005, available at http://www.bfff.co.uk/Market\%20 Dynamics\%20for\%20Frozen\%20April\%2005.doc.

158. Elisabeth Rosenthal, Even the French are Fighting Obesity, Int'L Herald TriB., May 4, 2005, available at http://www.iht.com/articles/2005/05/03/news/obese.php.

159. See Edgar, supra note 6, at 11 ; Arlie Russell Hochschild, Love and Gold, in Feminist Politics, Activism and Vision: Local and Global Challenges 34 (Luciana Ricciutelli et al. eds., 2004).

160. For instance, when people own washing and drying machines, they are more likely to wash their clothing more often than if they did not have the machines. See John P. Robinson, Dances with Dust Bunnies: Housecleaning in America-Women's Attitudes Towards Howecleaning, AM. DEMOGRAPHICs, Jan. 1997, available at http://www.findarticles.com/p/articles/mi_m4021/is_nl_v19/ ai_18976103/print. 
The demand for housekeepers and childcare providers is increasing in developed countries as women work longer hours outside the home. ${ }^{161}$ "[A] growing 'care industry' has stepped into the traditional wife's role, creating a very real demand for migrant women." ${ }^{162}$ However, many of these migrant women, some illegal, must leave behind their own children to be cared for by relatives. ${ }^{163}$ The children left at home by the migrants often suffer from physical and emotional illness, and some have difficulties at school. ${ }^{16+}$ " $[O]$ ne senses some sort of injustice at work, linking the emotional deprivation of these children with the surfeit of affection their First World counterparts enjoy." 165 The market places too low a value on the labor associated with raising children. ${ }^{166}$

The United States' heavy reliance on market mechanisms to address the problems facing today's families is wholly inadequate. "Since the 1930s, government has played a key role in keeping the American economy functioning well. ... So it is curious that we have not pursued a parallel course to provide protection for the American family, the great shock absorber of the boom-and-bust cycles of capitalism." 167

\section{B. Government Responses and Remedies}

Although some countries have relied primarily on the market to address the problems of families in the modern world, others have accepted that "care [is] a public value." 168 Indeed, many European governments, acknowledging the importance of children as a public good and embracing the "new" family, have enacted social programs that permit parents to spend more time with their families while balancing successful careers in the workforce. ${ }^{169}$ In France, for instance,

161. See Hochschild, supra note 159 , at 37.

162. Id.

163. See id. at 37-38; Edgar, supra note 6, at 11.

164. See Hochschild, supra note 159 , at 38 .

165. Id.

166. See id. at 43-44.

167. Arlie Russell Hochschild, Taking Care, The Am. Prospect, Apr. 8, 2002, at 47, available at http://www.prospect.org/print/V13/7/hochschild-a.html.

168. McClain, stupra note 57, at 1682.

169. See O'Connor-Felman, supra note 28 , at 1319. In some countries, however, a strong religious

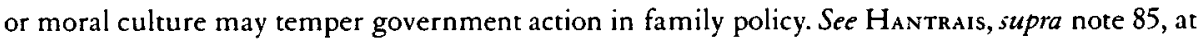
68. In Ireland, where 95\% of the population is Catholic, the Church still influences the role of women in society, thus tempering significant family-policy changes by the government. There has 
nearly 4.5 percent of the country's gross domestic product is spent on family services. ${ }^{170}$ This percentage could increase with the recent government-sponsored family reforms announced in September 2005. The French government announced new incentives to encourage parents to have a third child in order to boost the country's fertility rate. The government will pay $€ 750$ per month to a parent who takes a year of unpaid leave from work after the birth of a third child. ${ }^{171}$ Studies have shown that in countries with the greatest social benefits, there are lower levels of poverty. ${ }^{172}$ Moreover, in countries where there are extensive paid leave policies, there is a corresponding high level of participation by women in the workforce during their childbearing years. ${ }^{173}$

A variety of social programs may meet government goals. For instance, if the government wanted to focus on increasing the birth rate in order to increase that country's future economic viability, it could do so by directly providing money to families with children. ${ }^{174}$ If the government wanted to encourage mothers to participate in the work force, it could subsidize childcare expenses or provide state-sponsored childcare. ${ }^{175}$ Some governments may want to promote the "traditional" family, like Germany, and provide subsidies or tax credits to parents who stay home to care for the child. ${ }^{176}$

Government policies, while frequently beneficial to employees, can also harm the people they are designed to help. For instance, when a government limits the number of working hours, the policy could, in fact, hurt families who

been some advancement made; however, it is slow. Prior to 1973, under Irish law, women had to give up employment once they were married. Furthermore, until 1980, tax law discriminated against working, married women. Irish women now have more freedom in the workplace, but the lack of government-supported childcare continues to create a barrier for working mothers. See Fine-Davis ET al., supra note 20, at 68-69.

170. Jo Johnson, Financing the Family in France, Fin. Times, June 11, 2004, at 17. Part of the money earmarked for government family services is financed by employers' social contributions. See Fine-Davis Et al., supra note 20, at 15.

171. The government also announced that it would increase the tax incentives given to parents for the paid childcare of a child under the age of 6. Bremner, supra note 96; Objectif trois enfants, Radio FrancE, Sept: 23,2005 , htrp:/www.radiofrance.fr/reportage/laune/? $\mathrm{rid}=235000129 \& \mathrm{sarch}=1 \mathrm{simp}=1$.

172. Mishel Et AL., supra note 99, at 411-12,412 fig.7J. Of the OECD countries, the United States spends the least on social programs yet suffers the highest poverty rate. Id. at 411 .

173. See Lester, supra note 46 , at 40.

174. Id. at $5-6$.

175. Id. at 6 .

176. Id. 
really need the money or individuals who work either to gain economic independence from an abusive partner or to derive personal utility. ${ }^{17 \pi}$

Some government policies may inadvertently reinforce traditional gender roles. ${ }^{178}$ If policies are encouraging women to enter the workforce, there must be corresponding policies that encourage and allow men to shoulder more of the childcare responsibilities traditionally performed by women. For instance, a policy that provides either parent with unpaid time off after the birth of a child might still only be used by women, thus perpetuating the traditional caring role of the mother. However, if the father is given a "use-it-or-lose-it" paid time-off benefit, he might be more apt to take advantage of the benefit. ${ }^{179}$ A more effective policy encouraging fathers to take time off would be one where both parents are given paid time off for a specific period of time, for example six weeks; however, the parent is ineligible for the paid leave unless he or she takes the entire six weeks off. ${ }^{180}$

The following sections discuss different social programs enacted by governments, mostly European, to meet their family-policy goals. Overall, Sweden provides the most extensive state support to working parents. ${ }^{181}$

\section{Family Allowances and Tax Credits}

Several countries provide family allowances and tax credits that help to defray some of the costs associated with raising and training children. The United States does not directly subsidize childcare but instead provides working parents with a tax credit when they hire someone to care for a child under the age of thirteen or for another qualifying individual. ${ }^{182}$ The credit, known as the Child and Dependent Care Tax Credit, is based on adjusted gross income and cannot exceed $\$ 3,000$ for one child (or qualifying individual) and $\$ 6,000$ for two children (or qualifying individuals). ${ }^{183}$ The United States also provides some subsidy for lowincome families through the Earned Income Tax Credir (EITC). ${ }^{184}$ This provision

\footnotetext{
177. See Johnson, supra note 117 , at 1.

178. See Lester, supra note 46, at 79.

179. See id. at 80.

180. See id.

181. Den DuLk, supra note 97 , at 49.
}

182. I.R.C. $\$ 21$ (2000). A qualifying individual includes a cohabitating spouse or dependent who is physically and/or mentally incapable of caring for him or herself. I.R.C. $\$ 21$ (b)(1) (2000).

183. I.R.C. $\$ 21(c)(2000)$.

184. See I.R.S., Dept. of the Treasury, Earned Income Tax Credit (EITC) Questions and Answers, http:/ www.irs.gov/individuals/article/0,,id $=96466,00 . \mathrm{html}$ (last visited Oct. 3, 2005). See generally I.R.S. Publ'n 596: Earned Income Credit (EIC) (2004), available at http:/www.irs.gov/pub/irs-pdf/p596.pdf. 
provides a federal tax credit for qualifying low-income working families and individuals. Credits are greater for taxpayers with more than one child and may be refundable if the amount of the credit exceeds the tax owed. ${ }^{185}$ Finally, under the U.S. Child Tax Credit, a taxpayer is permitted a limited tax credit for each qualifying child. ${ }^{186}$

Like the United States, France also employs several family allowances and tax credit programs that encourage continued employment of the parent. Under the allocation de garde d'enfant à domicile (allowance for home childcare), where a working parent hires in-home help to care for children under the age of six, the state will cover a portion of the working parent's social security contributions for that childcare provider. ${ }^{187}$ Allowance recipients are eligible for a tax deduction of 50 percent of actual childcare costs. ${ }^{188}$ Furthermore, when either both parents or the sole parent work outside of the home, under the aide à la famille pour l'emploi d'une assistante maternelle agréée, they can receive an allowance to cover the social security contributions for childcare where there is at least one child under the age of six at home under the care of a registered childcare provider. Additionally, the family receives a financial payment. ${ }^{189}$ More than 38 percent of French parents with a child under the age of six prefer the use of a registered childcare provider to care for their child over any other childcare arrangement, including relatives. ${ }^{190} \mathrm{France}$ also employs the allocation parentale d'education (APE), a nontaxable fixed amount allocated to eligible families with two or more children, one of whom must be less than three years old. Under the APE, one of the parents must stop working completely or work part-time. The benefit stops once the youngest child turns three. ${ }^{191}$

While France's provisions encourage the parent to work, or to return to work after a paid leave, Germany, on the other hand, has adopted a policy that encourages one parent to stay at home and care for the child. Germany's tax code benefits the one-career family over the dual-income family. ${ }^{192}$

185. See I.R.S. Publ'n 596: Earned Income Credit (EIC) (2004), available at http://www.irs.gov/ pub/irs-pdf/p596.pdf; I.R.S., Earned Income Tax Credit (EITC) Questions and Answers, http://www. irs.gov/individuals/article/0, id =96466,00.html (last visited Oct. 3, 2005).

186. I.R.C. $\$ 24$ (2000); see also Lester, supra note 46 , at 7.

187. FINE-Davis ET AL., supra note $20, \S 2.1$, at 11 .

188. Id.

189. Id. at $\$ 2.2$.

190. Id. at 15 tbl.2.2.

191. Id. at 13.

192. See Cécile Wetzels, Squeezing Birth into Working Life: Household Panel Data Analyses Comparing Germany, Great Britain, Sweden and the Netherlands 33 (2001). 


\section{Maternity and Paternity Leave}

The physical and emotional development of a child is tied to the amount of time the parent spends bonding with the child after birth. Both parent and child benefit from time spent with each other. There is "a sense of personal achievement and intimacy on the part of the parent, and improved health on the part of the infant." ${ }^{193}$ When parents are financially capable of providing for their children, family stress decreases. When parents spend more time at home with their children, children tend to be healthier. ${ }^{194}$ It is therefore imperative that parents have employment options to enable them to financially support their families, and yet still have time to spend caring for them.

Maternity and paternity leaves vary tremendously across the industrialized states. Overall, however, it is mostly women who take advantage of these policies because of the social stigma attached to men who request parental leaves and the potential damage to their careers when they "reveal their preference to perform care work at home." ${ }^{195}$ Although maternity leaves do increase fertility rates for women in the paid workforce, because the leaves also increase the number of women in paid employment and women in paid employment have lower fertility rates than women who only work at home, some studies have found no overall effect linking paid maternity leave policies to overall fertility rates. ${ }^{196}$ The United States is one of only three industrialized countries in the OECD that does not require paid parental leave. ${ }^{197}$ Missouri and Montana, however, have been providing low-income parents with some monetary remuneration to care for infants and newly adopted children. ${ }^{198}$

European nations are more generous with parental leave policies. In France, mothers with one or two children are entitled to sixteen weeks of leave at full salary, subject to a monthly ceiling, while after the birth of a third child, working

193. Lester, supra note 46, at 18.

194. See id.

195. Margalioth, supra note 46 , at 326.

196. Lester, supra note 46 , at 46.

197. Mishel ET AL., supra note 99, at 410 . Australia and New Zealand are the two other countries that do not mandate paid leave upon the birth of a child. Id. The FMLA does allow an employee to take up to 12 weeks of unpaid leave to care for a newborn, but not every employee is eligible for FMLA benefits. 29 U.S.C. $\S \S 2602-2654$ (2000); see Mishel ET AL., supra note 99, at 410.

198. Lester, supra note 46 , at $8, n .33$. The French government has recently announced a new policy where a parent will be paid $€ 750$ per month to take a one-year unpaid leave from work after the birth of a third child. See Bremner, supra note 96. 
mothers can take up to six full months of paid leave. ${ }^{199}$ Fathers are also eligible for up to two weeks of paid leave after the birth of a child..$^{200}$

In Italy, mothers are entitled to five months of compulsory leave paid at 80 percent of their salary, although some organizations will pay the full salary. ${ }^{201}$ Mothers are also entitled to daily leave up to one to two hours per day, for one year at full pay, for breastfeeding. ${ }^{202}$ Paternity leave in Italy is not as generous; but, where the father is the sole parent for the child due to the mother's death, incapacitation, or unavailability, he may be eligible for twelve weeks of paid leave at 80 percent salary. ${ }^{203}$

In England, mothers are entitled to eighteen weeks of paid leave. The first six weeks are paid at 90 percent of the mother's salary and the remaining twelve weeks leave is paid at a flat rate. ${ }^{20 t}$ Mothers who have been with their employer for longer than a year are eligible for an additional twenty-nine weeks of paid leave after childbirth. England offers no statutory leave polices for fathers. ${ }^{205}$ In Ireland, mothers are entitled to eighteen weeks of maternity leave at 70 percent pay and an additional eight weeks of unpaid maternity leave, with both leaves counting toward annual leave accrual. Women are also entitled to limited paid time off for breastfeeding for the first four months after the child's birth. ${ }^{206}$ There is no state-mandated paternity leave, but civil service fathers are entitled to three paid days following the birth of the child..$^{20}$

Sweden has very generous parental-leave policies, equal for both mothers and fathers. After the birth of a child and up until the child turns eight years of age, parents are entitled to take 360 days of leave paid at 80 percent of wages and an additional ninety days leave at a flat rate. ${ }^{208}$ To be eligible, however, a parent must have been employed for at least six months prior to childbirth or for a period of twelve months over two years prior to birth. ${ }^{209}$ Additionally, a mother may take fifty days prior to the birth, paid at 80 percent, if the mother is in a po-

199. Fine-Davis et AL., supra note 20, at 11-12, 82 tbl.6.5.

200. Id. at 12,83 tbl.6.5.

201. See id. at 25,82 tbl.6.5.

202. See id.

203. See id. at $11-12,83$ tbl.6.5.

204. Den Dulk, supra note 97 , at 43.

205. Id. at 48 fig.2.2.

206. See Fine-Davis et al., supra note 20, at 56.

207. See id. at 57.

208. Den Dulk, supra note 97, at 45, 49 fig.2.2.

209. Id. at 44 . 
sition that requires heavy, physical work and the employer cannot transfer her to a position with lighter duties. This leave is not carried over beyond the birth, when parental leave begins. ${ }^{210}$ Fathers may also take paternity leave of ten days paid at 80 percent anytime within the first two months after birth. ${ }^{211}$

\section{Family and Medical Leave}

Paid family leave is an ideal policy because the parent can take time off to spend more time with the family without financial worry. The United States has the least generous family-leave policies among OECD countries. ${ }^{212}$ As previously discussed, the FMLA entitles an employee to take up to twelve weeks of unpaid leave per year to care for oneself or a family member who is seriously ill. However, to be eligible, the employee must have been employed for at least one year and have worked at least 1,250 hours in the previous year. ${ }^{213}$ Because the FMLA is only applicable to government employers and private organizations with fifty or more employees, only 77 percent of all U.S. employees work for an employer covered by the FMLA, and of these employees, only 62 percent are actually eligible for the leave. ${ }^{214}$ Furthermore, because the FMLA benefits are unpaid, workers are reluctant to take time off, especially the full twelve weeks, without some financial security. ${ }^{215}$

By contrast, in France, either parent who has been with the company for at least one year can take either full-time unpaid leave or work part-time until the child is three years of age. After the leave, the parent is entitled to be reinstated to the same or a similar position at the same pay. ${ }^{216}$ Although this parental leave is unpaid, the state does provide some monetary benefits to eligible families under the APE program. ${ }^{217}$

In Italy, mothers are eligible to take an optional six months of parental leave paid at 30 percent before the child turns eight. ${ }^{218}$ Traditionally, few women take

210. Id. at 45,49 fig. 2.2 .

211. Id. at 45 .

212. Lester, supra note 46 , at 3.

213. 29 U.S.C. $\$ 2611(2000)$.

214. 149 Conc. Rec. S1980 (daily ed. Feb. 5, 2003) (statement of Sen. Dodd).

215. See Lester, supra note 46, at 3.

216. See Fine-Davis et al., supra note 20, at 13.

217. See id. Under the APE program, families with 2 or more children and at least one of the children under the age of 3 are eligible to receive a flat, nontaxable rate if one of the parents either works part-time or withdraws from the market entirely. Id.

218. See id. at $25,84 \mathrm{tbl} .6 .5$. The first 30 days are paid at $100 \%$ for public-sector employees. Id. 
advantage of this extended leave, instead opting to return to work after childbirth, but with reduced hours. ${ }^{219}$ Fathers may also be eligible for the optional sixmonth leave if the mother is unable to take advantage of it. ${ }^{220}$ Ireland offers fourteen weeks of unpaid parental leave to each parent, which can be taken anytime before the child turns five. ${ }^{221}$

In addition to the 450 days of parental leave discussed in the section above, Swedish parents are entitled to take unpaid leave until the child is one and a half years old. After the child reaches this age, the parent can still use the parental leave. ${ }^{222}$ Swedish parents are also entitled to sixty days off per year when the child or caregiver is ill and an additional sixty days to care for "closely-related" family members, paid at 80 percent. ${ }^{223}$

\section{Childcare and Education}

Several European countries further reduce the costs borne by families associated with raising and training a child by providing quality, affordable, and in some cases, free daycare and nursery schooling for children under the age for compulsory education. In France, the National Ministry of Education provides complimentary écoles maternelles for children between the ages of two and six. Approximately 36 percent of all two-year-old children and 98 percent of all three-year-old children attend the écoles maternelles. ${ }^{224}$ The state has also established crèches collectives, which are state-subsidized daycare centers for children under the age of three, and crèches familiales, where licensed childcare providers watch no more than three children in their own homes. The fees for both types of crèches are based on income. ${ }^{225}$

Italy has very limited state-sponsored childcare facilities because the government has delegated the care of children to families. Italy does provide some crèches, with the fees based on income. ${ }^{226}$ Childcare is very similar in England where there are minimal public childcare facilities except for families in need.

219. See id. at 25.

220. See id. at 11-12,84 tbl.6.5. Fathers may take a 7 -month leave if they have already taken their 3 -month paternity leave. Id.

221. See id. at 84 tbl.6.5.

222. Den Dulk, supra note 97, at 46.

223. Id. at 49 fig.2.2.

224. Fine-Davis et al, supra note 20, at 11.

225. Id. at 10.

226. Id. at 23-24. 
Less than 1 percent of children under the age of four attend public nursery schools. Beginning at age three, children may attend nursery school free of charge; however, these schools are often only offered part-time. ${ }^{227}$ Ireland has no statutory childcare provisions because, as in Italy, childcare is left to families. Compulsory education in Ireland begins at six years; however, there are some public schools that provide schooling for children ages three to five. ${ }^{228}$ In Sweden, children between the ages of one and twelve may attend public childcare centers. However, the parents must either be working or in school. Close to 75 percent of all children between the ages of one and six attend these facilities. ${ }^{229}$ Japan has only recently begun to offer some childcare facilities to help working mothers through its "Angel Plan," "New Angel Plan," and the recent "Plus One Proposal."230

\section{Statutorily Imposed Alternative Work Arrangements and Reduced Hours}

Most flexible work arrangements are market-driven; however, a few countries have enacted laws governing part-time and reduced-hours employment. Under the generous Swedish family law, parents have the right to work six-hour days until the child turns eight. ${ }^{231}$ Under the Dutch Adjustment of Hours Act of 2000 , employees may request a reduction or increase in the hours worked. ${ }^{232}$ The employer must accept the request unless the employer can demonstrate a valid business reason why the requested change in hours would be detrimental to the business. ${ }^{233}$ However, because 68 percent of women in the Dutch labor force work part-time, this act rarely benefits mothers. It is more often used by fulltime employees, including some fathers, who would like to periodically reduce their hours worked. ${ }^{234}$

In 1998, in an attempt to improve the unemployment rate and work-life balance, France adopted La Loi Aubry I, which created a thirty-five hour work-

227. Den DulK, supra note 97, at 43.

228. FINE-Davis ET AL, supra note 20, at 57.

229. Den Dulk, supra note 97 , at 46-47.

230. Jonathan Head, Japan Sounds Alarm on Birth Rate, BBC News, Dec. 3, 2004, available at http://news.bbc.co.uk/2/hi/asia-pacific/4065647.stm.

231. Den Dulk, supra note 97, at 49 fig.2.2; O'Connor-Felman, supra note 28, at n.389; see Jeff Madrick, Economic Scene: Working Families Are Often Among the First to Suffer When a Country Loses Its Sense of Optimism, N.Y. Times, Dec. 26, 2002, at C2.

232. Den Dulk, supra note 97, at 48 fig.2.2; see Berg et al., supra note 128, at 339.

233. See Berg et al., supra note 128, at 339; DEN Dulk, supra note 97, at 48 fig.2.2.

234. Berg et al., supra note 128 , at 339. 
week. ${ }^{235}$ Employers were offered subsidies to implement the thirty-five hour week and create new jobs while decreasing working time by 10 percent. ${ }^{236}$ In 2000 , the legislature enacted $A u b r y I I,{ }^{23}$ which provided more flexibility by relaxing the use of overtime and permitting employers to modify work schedules throughout the year so that employees can work more hours during periods of peak production and fewer hours during the slower periods. ${ }^{238}$ Unfortunately, the thirty-five hour work week policy was a failure. By January 2005 , unemployment had climbed to 10 percent and, because of the restrictions placed on organizations, the French economy had lost some of its competitive edge in the market. ${ }^{239}$ Although the law has not been repealed, employers may now offer employees extra hours at a higher wage. ${ }^{240}$ As previously discussed, statutorily imposed restrictions limiting the number of hours worked can hurt not only the people they are intended to benefit but also the employers and even the country's economy. A more successful policy is the Swedish policy described above where the parent has the option of reducing his or her hours if his or her personal circumstances permit.

Rather than restricting hours worked, some governments have enacted policies that protect employees who work reduced hours and help parents balance work and family. In the Netherlands, for example, the Equal Treatment Act of 1993 prohibits an employer from discriminating against part-time workers. Part-time wages, benefits, positions, and training must all be comparable to those of full-time positions. ${ }^{2+1}$ Ireland has also recently enacted a law that prohibits employers from discriminating against part-time employees. ${ }^{242}$

Japan recently enacted legislation that encourages women to work, yet also provides flexibility to working mothers. ${ }^{243}$ Japanese policy is designed to increase birth rates and address the economic problems associated with the rapidly

235. See Law No. 98-461 of June 13, 1998, Journal Officiel de la République Française [J.O.][Official Gazette of France], June 14, 1998, p. 9029; see also Fine-Davis et al., supra note 20, at 19.

236. See Schultz \& Hoffman, supra note 31 , at 11.

237. Law No. 2000-37 of Jan. 19, 2000, Journal Officiel de la République Française [J.O.] [Official Gazette of France], Jan. 20, 2000, p. 975.

238. See Schultz \& Hoffman, supra note 31, at 12.

239. See 35-hour Working Week a Dismal Failure, supra note 154, at 32.

240. Id.

241. Berg et al., supra note 128 , at 339 .

242. See Fine-Davis Et aL., supra note 20, at 60.

243. Interestingly, there are no statutory protections for part-time employees in Japan. See Berg et al., supra note 128 , at 344 . 
aging population..$^{244}$ Under the first "discretionary work" or "super-flextime" scheme, employees, with the consent of the employer, are free to set their own daily hours, if they meet the minimum number of hours required per month. ${ }^{245}$ Under the "averaging weekly working hours" scheme, employers may average the employee's hours to accommodate varying workloads throughout the business cycle, but the average hours may not be greater than fifty-two hours per week and ten hours per day. ${ }^{246}$

\section{Conclusion}

The demands of the global economy are impinging on people's desire to marry and have children. International free trade agreements and improvements in transportation and information technology have placed workers around the world in competition with each other and undermined long-term employment relationships. As a result, workers in the global economy are subject to more job and geographic dislocations, straining their ability to form family relationships and provide a stable environment for childrearing. In order to obtain jobs in the new global economy, young people in the developed world are required to undertake years of training and career development. This extended period of training raises the costs of having children and directly interferes with people's prime family formation and childbearing years. Moreover, the global economy is demanding more paid labor from couples in developed countries as they struggle to maintain their standard of living. These longer work hours divert time people would otherwise spend on childrearing and child education. These problems have become serious enough that most developed countries are declining in population or maintaining their populations only through immigration.

In order to solve this problem, the countries of the developed world will have to rely on both market and governmental solutions. Private employers can address this problem by designing flexible work hours and policies that meet the needs of families. The market can respond by providing market services in cleaning, food preparation, and childcare that cater to working families. However, market solutions will not be enough. Children, and the investment we

244. Id. at 343 .

245. Id. at 343-44. Less than $2 \%$ of employers use this scheme. Many employers offer other types of flexible schedules to accommodate employee family responsibilities. Id. at 344 .

246 . Id. at 344 . Roughly $36 \%$ of Japanese organizations average weekly working hours. Id. 
make in them, are public goods, which will be undersupplied unless employers and the rest of society who enjoy some of the benefits of each new generation also bear some of their cost. Accordingly, the governments of the developed world should undertake programs that sufficiently provide or subsidize childcare and education to the extent necessary to solve the problem. This essay provides a catalog of government efforts in this regard in the developed world. 
